\title{
Somogy megye gömblegyeinek katalógusa (Diptera: Acroceridae)
}

\author{
MAJER JÓZSEF
}

MAJER J.: Checklist of Acroceridae of Somogy county (Diptera: Acroceridae)

Abstract: The Palaearctic fauna of Acroceridae consists of 85 species and 12 genera, but the number of species may increase to about 100. There are 6 known species of 2 genera in Hungary, one of them was collected in Somogy county.

\section{Bevezetés}

Lárvája pókokban él. Ritka, bonyolult fejlődésmenetú, kisebb méretû́, feltúnően domború, többnyire gömb alakú legyek. Hazánkból eddig 6 fajuk ismert (MAjer 1977), de még legalább ennyi előfordulása valószínúsíthetô. A Palearktikumból leírt 12 nemzetségbe 85 faj tartozik, de az akár 100-ra is emelkedhet. Mivel az imágó rövid életû́ és az aránytalanul nagy teste és kicsi szárnya miatt kevéssé mozgékony, még a nagyon szisztematikus gyưjtốk is csak ritkán fogják az ide tartozó fajokat. A rendszeres pókgyújitésekkel az Arachnoidea fajokkal együtt a gömblegyeket is megtaláljuk. Nem véletlen az, hogy a legtöbb gömblegyet éppen a pókokat gyưitó́k fogták. Eddig egy, még nem publikált példányt fogtak a Barcsi-Borókásból, 1998-ban. Azt, hogy hány faj kerül eló még Somogy megyéből a hazánkban feltételezett 12-ból, az kizárólag a gyúitoók aktivitásán múlik.

\section{Somogyból ismert faj}

\section{Acroceridae}

Ogcodes varius Latreille, 1811.

Majer J.

1. táblázat: Somogyból ismert fajok száma

\begin{tabular}{|l|c|}
\hline Rend, Család & Fajszám \\
\hline Diptera & \\
\hline Acroceridae & 1 \\
\hline
\end{tabular}

ISSN 1587-1908 (Print); ISSN 2062-9990 (Online) 


\title{
Irodalom
}

MaJER, J. 1977: Katonalegyek - Gömblegyek. Fauna Hungariae Akadémiai Kiadó, XIV/10. p. 75.

\section{Checklist of Acroceridae of Somogy county (Diptera: Acroceridae)}

\author{
JóZSEF MAJER
}

Hitherto 6 acrocerid species are known in Hungary. One of them was collected in Somogy county. The imagous are short lived, they are active only on warm sunny days. Most of them were collected by spider researchers. Six more species are expected from Hungary. Any of them may be collected from Somogy county.

Author's address:

Dr. József MAjer

Department of General and Applied Ecology

University of Pécs

H-760l Pécs

Ifjúság útja 6 .

HUNGARY 